\title{
Bortezomib-thalidomid-dexametazon- terápiára refrakter myeloma multiplexes esetek elemzése két budapesti centrum adatai alapján
}

\author{
Tóth András Dávid ${ }^{1,2}$, Varga Gergely ${ }^{1}$, Wohner Nikolett ${ }^{1}$, Farkas Péter ${ }^{1}$, \\ Horváth Laura ${ }^{1}$, Szombath Gergely ${ }^{1}$, Ceglédi Andrea ${ }^{3}$, Kozma András ${ }^{3}$, \\ Reményi Péter ${ }^{3}$, Masszi Tamás ${ }^{1}$, Mikala Gábor ${ }^{3, @ ~}$ \\ ${ }^{1}$ Semmelweis Egyetem, III. sz. Belgyógyászati Klinika, Budapest \\ ${ }^{2}$ MTA-SE Molekuláris Élettani Kutatócsoport, Budapest \\ ${ }^{3}$ Dél-pesti Centrum Kórház - Országos Hematológiai és Infektológiai Intézet, Budapest
}

\begin{abstract}
A bortezomib-thalidomid-dexametazon- (VTD-) alapú rezsim az egyik leggyakrabban alkalmazott kemoterápiás protokoll a myeloma multiplex első vonalbeli kezelésében Magyarországon. A válaszarány jelentős, de előfordulnak refrakter esetek is. Sokszor ekkor is hatásosak lehetnek az új, de jelentős költségű másodvonalbeli szerek, ezért a VTD-refrakteritás mihamarabbi felismerése fontos feladat. Nem ismert, hogy mely esetekben számíthatunk VTD-terápiára elégtelen válaszra. Ennek vizsgálatára 16, a Dél-pesti Centrum Kórházban és a Semmelweis Egyetem III. sz. Belgyógyászati Klinikáján 2009 és 2019 között kezelt VTD-refrakter beteg adatait elemeztük retrospektíven. Meglepő módon a refrakter betegek többsége nem rendelkezett az ismert kedvezőtlen prognosztikai faktorokkal. A szérum $\beta 2$-mikroglobulin-, albumin-, LDH-szintekben a kiugró eltérések nem voltak jellemzőek, továbbá csak két esetben találtunk magas kockázattal járó citogenetikai (del( $17 \mathrm{p})$, illetve $\mathrm{t}(4 ; 14))$ elváltozást. A másodvonalbeli kezelésig medián 89 nap telt el, és amennyiben lehetséges volt, a terápia során törekedtünk autológ őssejt-transzplantáció végzésére. A másodvonalbeli kezelésre a betegek többsége már jól reagált, 16-ból 10 esetben nagyon jó részleges válasz vagy komplett remisszió lépett fel. A VTD-refrakter betegek medián túlélése 47 hónap volt, ami összevethető a nem VTD-refrakterek túlélési adataival.

Következtetésként elmondható, hogy az eddig használt prognosztikai faktorok nem alkalmasak a VTD-refrakteritás előrejelzésére myeloma multiplexben. Az adatok felhívják a figyelmet új markerek szükségességére, melyek segítségével korábban juthatna ez a betegpopuláció hatékony terápiához, valamint a kezelés során végzett szoros kontroll fontosságára, hogy mielőbb felismerjük a terápiaváltás szükségességét.
\end{abstract}

Kulcsszavak: myeloma multiplex, bortezomib, thalidomid, dexametazon, refrakter

\section{Evaluation of bortezomib-thalidomide-dexamethason refractory cases of multiple myeloma treated in two centers in Budapest}

The bortezomib-thalidomide-dexamethason (VTD) regimen is one of the most commonly applied first-line therapy in multiple myeloma in Hungary. The response rate is considerable, but there are refractory cases as well. The novel but expensive second-line drugs are often effective in these cases, thus the early identification of non-responders to VTD has critical importance. The risk factors for VTD-refractory myeloma are not known. Therefore, we retrospectively analyzed the data of 16 patients refractory to VTD treated between 2009 and 2019 in two centers of hematology in Budapest, Hungary. Strikingly, the majority of the patients refractory to VTD had no poor prognostic factors. Major differences in serum $\beta 2$-microglobulin, albumin, and LDH levels were not characteristic, and high-risk cytogenetic abnormalities (del $(17 \mathrm{p})$ and $\mathrm{t}(4 ; 14))$ were only observed in two cases. Second-line therapy was initiated after median 89 days, and if it was possible, autologous stem cell transplantation was performed. Most of the patients responded well to the

@ Levelezési cím: Dr. Mikala Gábor, Budapest, Albert Flórián út 5-7., 1097; E-mail: gmikala@dpckorhaz.hu 
second-line regimen: very good partial response or complete remission was observed in 10 of the 16 patients. Median survival of patients' refractory to VTD was 47 months that is comparable to the survival of non-refractory patients.

In summary, the generally accepted prognostic factors are not suitable to predict refractory multiple myeloma. Our results call attention to the need of new markers that could help these patients get earlier effective therapy. Moreover, close monitoring during induction is necessary to recognize refractoriness.

Keywords: multiple myeloma, bortezomib, thalidomide, dexamethason, drug resistance

(Beérkezett: 2019. október 23.; elfogadva: 2019. november 11.)

\begin{abstract}
Rövidítések
ASCT = autológ őssejt-transzplantáció; $\mathrm{CR}=$ komplett válasz; EDAP = etopozid, dexametazon, citarabin, ciszplatin; FISH = fluoreszcens in situ hibridizáció; HD cyclo + Benda/Mel ASCT = magas dózisú ciklofoszfamid őssejt-mobilizálás, bendamustin, melfalán autológ őssejt-transzplantáció; IRD = ixazomib, lenalidomid, dexametazon; KRD = carfilzomib, lenalidomid, dexametazon; $\mathrm{MM}=$ myeloma multiplex; $\mathrm{PAD}=$ bortezomib, doxorubicin, dexametazon; $\mathrm{PD}=$ progresszív betegség; $\mathrm{PR}=$ parciális válasz; $\mathrm{RD}=$ lenalidomid, dexametazon; $\mathrm{R}-\mathrm{ISS}=$ revised international staging system; $\mathrm{sCR}=$ szigorú komplett válasz; SD = stabil betegség; VDTC = bortezomib, dexametazon, thalidomid, ciklofoszfamid; VDT-PACE = bortezomib, dexametazon, thalidomid, ciszplatin, doxorubicin, ciklofoszfamid, etopozid; VD-venetoclax = bortezomib, dexametazon, venetoclax; VGPR = nagyon jó parciális válasz; $\mathrm{VRD}=$ bortezomib, lenalidomid, dexametazon; VRD-PACE $=$ bortezomib, lenalidomid, dexametazon, ciszplatin, doxorubicin, ciklofoszfamid, etopozid; VTD = bortezomib, thalidomid, dexametazon
\end{abstract}

\section{Bevezetés}

A myeloma multiplex (MM) a plazmasejtek daganatos megbetegedése, a 2. leggyakoribb malignus hematológiai kórkép Magyarországon [1]. A betegségre a csontvelő klonális plazmasejt-szaporulata mellett a klinikai tünetek és a szervi eltérések sokszínűsége jellemző, a leggyakoribbak ezek közül a hypercalcaemia, a vesekárosodás, az anaemia és a csontléziók [2]. A klinikai megjelenés változatosságát részben magyarázza a myeloma multiplex kialakulásáért felelős patogenetikus citogenetikai abnormalitások rendkívüli sokrétúsége [3]. Az alapító genetikai eltéréseket két nagy csoportba sorolhatjuk: hiperdiploid és immunglobulin nehézlánc gént érintő (leggyakrabban a $\mathrm{t}(11 ; 14), \mathrm{t}(4 ; 14), \mathrm{t}(6 ; 14), \mathrm{t}(14 ; 16)$ és $\mathrm{t}(14 ; 20)$ reciprok kromoszómatranszlokációkból eredő) myelomás eseteket különböztethetünk meg. Ezek mellett számos másodlagos citogenetikai elváltozás is előfordulhat, melyek közül gyakoribb a del(13q), a del(17p), a del(1p) és az 1qamplifikáció. Ezen másodlagos eltérések, különösen a del(17p), általában kedvezőtlen prognózissal társulnak. Továbbá számos szomatikus mutációt azonosítottak myeloma multiplexes esetekben, melyek leggyakrabban a mitogén-aktivált protein kináz (MAPK), a nukleáris faktor $\kappa \mathrm{B}(\mathrm{NF \kappa B})$, a foszfoinozitol-3-kináz (PI3K)-Akt jelátviteli útvonalakat, a sejtciklus szabályozó folyamato- kat, a plazmasejtérést és a DNS-hiba felismerő és javító mechanizmusokat érintik [3]. Az utóbbi évek fontos felismerése, hogy nemcsak intertumorális heterogenitás (különböző betegek tumorainak eltérő biológiai viselkedése), hanem intratumorális heterogenitás is létezik, azaz a betegben a betegség felismerésekor már több, különböző genetikai eltérésekkel rendelkező malignus klón fejlődött ki [3]. E klónok terápiaérzékenysége különböző lehet, és sokszor a kezelés a rezisztens klónok szelekcióját váltja ki, ami érthetővé teszi a relapszusok gyakoriságát.

A klonális megbetegedésnek megfelelően legtöbb esetben megfigyelhető a monoklonális immunglobulinszaporulat és/vagy a szabad $\kappa$ vagy $\lambda$ láncok mennyiségének abszolút és relatív emelkedése. A további gyakori laboratóriumi eltéréseket, mint a szérum LDH-, $\beta_{2}$-mikroglobulin-szint emelkedését vagy az albuminkoncentráció csökkenését, gyakran prognosztikai faktorokként is alkalmazzuk [1]. A rizikótényezők komplex elemzésére alkalmas az R-ISS (revised international staging system) stádiumbeosztás, ami együttesen vizsgálja az LDH-, albumin-, $\beta_{2}$-mikroglobulin-szintek eltéréseit és a kedvezőtlen prognózisú citogenetikai abnormalitások jelenlétét [4]. Az R-ISS három stádiumot határoz meg, melyek különböző kórlefolyással társulnak.

A myeloma multiplex potenciálisan kuratív célú terápiája az autológ őssejt-transzplantáción és a gyógyszeres kezelésen alapul. A kemoterápiában az utóbbi években proteoszóma-inhibitorok (bortezomib, carfilzomib és ixazomib) és az IMiD-ek (thalidomid, lenalidomid, pomalidomid) kerültek középpontba a glükokortikoidok mellett [5]. Itthon első vonalban e szerek közül finanszírozási okok miatt a bortezomib és a thalidomid érhető el. Relabáló vagy refrakter esetekben az újabb, de költségesebb szerek is adhatóak, az immunterápia (CD38-ellenes antitest, daratumumab) is hatékony lehet [6], továbbá a terápiát a hagyományos citotoxikus szerekkel is kiegészíthetjük.

Mivel a bortezomib-thalidomid-dexametazon- (VTD) terápiára nem válaszoló esetekben szerencsére ma már sok új alternatív kezelési lehetőségünk van, fontos lenne tudnunk, hogy mely betegek esetében várható VTD-refrakteritás. Ezek az ismereteink azonban sajnos még korlátozottak, ezért célul tûztük ki a VTD-terápiára refrakter betegek klinikai paramétereinek elemzését. 


\section{Módszer}

Retrospektív vizsgálatunkban 2009 és 2019 között a Délpesti Centrum Kórházban vagy a Semmelweis Egyetem III. sz. Belgyógyászati Klinikáján kezelt VTD-refrakter betegek adatait elemeztük. Az alkalmazott protokollban az első ciklusban heti kétszeri 1,3 mg/m² bortezomib (1., 4., 8., 11 . nap), két héten keresztül heti négyszeri $40 \mathrm{mg}$ dexametazon (Dél-pesti Centrum Kórház) vagy dózisekvivalens metilprednizolon (Semmelweis Egyetem III. sz. Belgyógyászati Klinika) és napi $100 \mathrm{mg}$ thalidomid adása szerepelt, majd a második ciklustól bortezomib és szteroid alkalmazása heti egyszer történt. Refrakternek a VTD-kezelés során progrediáló betegséget, illetve a minimális választ sem elérő eredményt tekintettük. Az analizált betegeknél nem történt érdemi dózismódosítás vagy kihagyás, a gyógyszerkihagyás alatt progrediáló betegeket nem vettük be a vizsgálatba. Kérdésünk volt, hogy milyen klinikai jellegzetességgel bír a VTD-refrakter betegcsoport, illetve mely klinikai paraméterek határozzák meg a túlélésüket. Meghatároztuk a paraméteres adatok átlagát és szórását, ill. a nonparametrikus adatok százalékos megoszlását. Az össz- és a progressziómentes túlélés statisztikai értékelésére a Kaplan-Meiermódszert alkalmaztuk. Elemzésre több különböző módon alcsoportokat képeztünk: I., R-ISS stádium, II., a betegség csontvelői érintettsége eléri-e az 50\%-ot vagy sem, III., $\mathrm{t}(11 ; 14)$ transzlokáció jelenléte vagy hiánya, IV., a másodvonalbeli kezelésre adott válasz legalább nagyon jó parciális válasz (nagyon jó parciális válasz (VGPR), komplett válasz (CR), szigorú komplett válasz (sCR) vagy ennél rosszabb (parciális válasz (PR), stabil betegség (SD), progresszív betegség (PD)). Kontrollcsoportnak a Semmelweis Egyetem III. sz. Belgyógyászati Klinikáján a vizsgálati időszakban kezelt teljes myeloma multiplex betegpopulációt vettük a VTD-refrakterek kivételével. Az adatokat átlag \pm standard hiba formában ábrázoltuk, és ha külön nem jelöltük, a diagnózis felállításakor mért paramétereket adtuk meg.

\section{Eredmények}

A vizsgált időszakban kritériumainknak 16 beteg (a VTDvel kezeltek körülbelül 6\%-a), köztük 9 férfi és 7 nő felelt

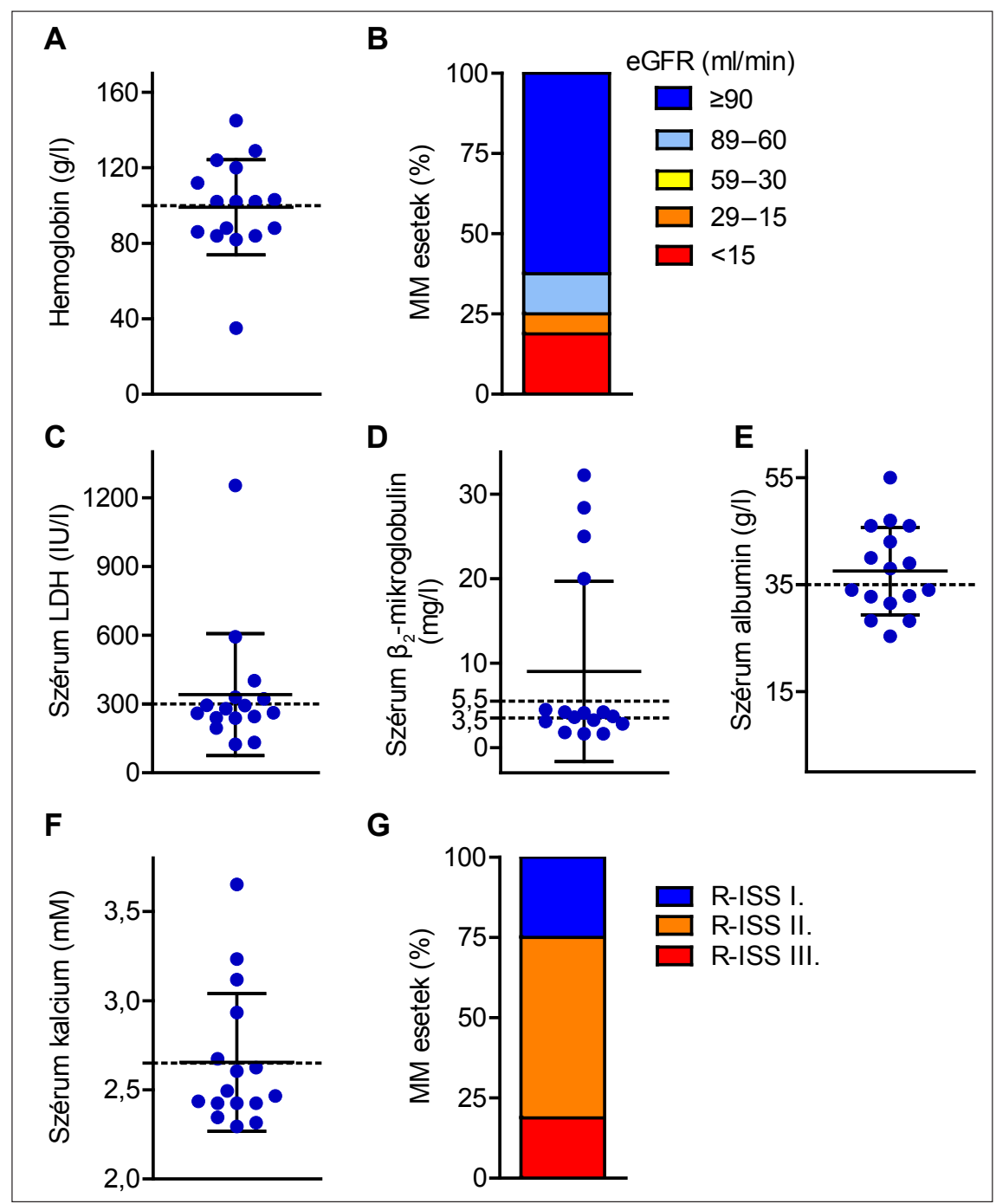

1. ábra. A VTD-refrakterek vérparaméterei és az R-ISS szerinti stádiumok megoszlása 
meg, diagnóziskor életkoruk medián 47,8 (28,3-69,7) év volt, ami jóval alatta van a myeloma szokásos jelentkezési idejénél. Nehézlánc alapján 6 IgG, 3 IgA, 1 IgM myeloma, továbbá 6 könnyưlánc myeloma állt fenn. A könnyúlánc 9 esetben $\kappa, 7$ esetben $\lambda$ volt. Lítikus csontlézió 13 esetben $(81 \%)$ fordult elö, a betegség csontvelői érintettsége az esetek felében volt legalább 50\%-os. A betegek többsége $(75 \%)$ anaemiás volt, $100 \mathrm{~g} / 1$ alatti hemoglobin koncentrációt pedig az esetek 44\%-ában észleltünk ( $1 \mathrm{~A}$. ábra). Jelentősen beszűkült vesefunkció ( $60 \mathrm{ml} / \mathrm{min}$ alatti eGFR) azonban a betegek kisebb hányadában (25\%) alakult ki (1B. ábra ). Meglepő módon a VTD-refrakterek többsége nem rendelkezett jelentősen eltérő szérum $\beta_{2}$-mikroglobulin-, LDH-, albumin- vagy kalciumszintekkel ( $1 C$ F. ábra). Csak 4 esetben (25\%) detektáltunk magas rizikót jelentő, $5,5 \mathrm{mg} / \mathrm{l}$ feletti $\beta_{2}$-mikroglobulin-szintet, $300 \mathrm{IU} / \mathrm{l}$-t meghaladó LDH-szintet pedig csak 5 esetben (31\%). Hypalbuminaemia (35 g/l alatti albuminkoncentráció) az esetek felében lépett fel. Magas kockázattal járó citogenetikai eltérést (del $(17 \mathrm{p}), \mathrm{t}(4 ; 14)$ és/vagy $\mathrm{t}(14 ; 16))$ csak 2 esetben azonosítottunk $(\mathrm{t}(4 ; 14)$ ill. $\mathrm{t}(4 ; 14)+$ del(17p)), az egyéb citogenetikai eltérések közül 4 esetben $\mathrm{t}(11 ; 14)$ transzlokációt és 7 esetben $1 \mathrm{q}$-amplifikációt észleltünk. Az R-ISS beosztás szerinti magas rizikójú csoportba mindössze 3 beteg tartozott (1G. ábra). Ezek az adatok arra utalnak, hogy a hagyományosan elfogadott prognosztikai faktorok nem alkalmasak az elégtelen VTD-érzékenység előrejelzésére.

A VTD-refrakterek másodvonalbeli kezelésének megkezdéséig medián 89 nap telt el. Az alkalmazott másodvonalbeli kezelési protokollokat az 1. táblázat foglalja össze, annak típusa mindig eseti elbírálás után került kiválasztásra. Amennyiben lehetséges volt, törekedtünk autológ őssejt-transzplantáció végzésére a másodvonalbeli terápia során. Az adatok elemzésének időpontjáig 11 beteg részesült autológ őssejtátültetésben, 2 esetben pedig elvégzését terveztük. A VTD-refrakteritás ellenére a betegek többsége a másodvonalbeli kezelésre már jól reagált, és aminek hatására a progressziómentes túlélés (PFS) medián 17 hónap volt ( $2 A$. ábra). Nagyon jó parciális választ (VGPR) 8 esetben, és egy esetben még szigorú komplett választ ( $\mathrm{sCR}$ ) is tapasztaltunk (VGPR vagy sCR összesen 56\%-ban volt). Parciális válasszal (PR) 2 esetben, stabil betegséggel (SD) pedig 4 esetben találkoztunk. A kombinált rossz prognózisú citogenetikai eltérésekkel bíró beteg esetében a terápiaváltás ellenére is progrediált a betegség (PD). A másodvonalbeli kezelésre adott terápiás válasz nagymértékben meghatározta az össztúlélést (OS): ha legalább nagyon jó parciális választ értünk el, a betegek túlélése szignifikánsan jobbnak bizonyult a rosszabbul válaszolókéhoz képest (2B. ábra). Ezzel szemben a csontvelői érintettség mértéke és a túlélés között nem talál-

1. táblázat. Betegkarakterisztika és válasz a mentő kezelésre

\begin{tabular}{|c|c|c|c|c|c|c|c|c|c|}
\hline & Nem & Életkor & Nehézlánc & Könnyülánc & R-ISS & FISH & Salvage & ASCT & Válasz \\
\hline 1 & nő & 46 & & kappa & I & N.A. & $\begin{array}{l}\text { HD cyclo + } \\
\text { Benda/Mel ASCT }\end{array}$ & igen & VGPR \\
\hline 2 & férfi & 56 & $\operatorname{IgA}$ & kappa & I & $\mathrm{t}(11 ; 14)$ & IRD & igen & $\mathrm{SD}$ \\
\hline 3 & férfi & 50 & & lambda & III & $\mathrm{t}(11 ; 14)$ & VRD-bendamustin & igen & $\mathrm{SD}$ \\
\hline 4 & nő & 39 & IgG & lambda & II & $+11,-13, \operatorname{amp}(1 \mathrm{q})$ & $\mathrm{RD}$ & igen & VGPR \\
\hline 5 & nő & 49 & & kappa & I & $\mathrm{t}(11 ; 14), \operatorname{amp}(1 \mathrm{q})$ & VD-venetoclax & terv & sCR \\
\hline 6 & férfi & 40 & $\operatorname{IgM}$ & kappa & I & $\mathrm{t}(11 ; 14)$ & VDTC+ASCT & igen & VGPR \\
\hline 7 & férfi & 57 & $\operatorname{IgA}$ & lambda & II & $\mathrm{t}(4 ; 14), \operatorname{del}(17 \mathrm{p})$ & $\mathrm{PAD}$ & nem & $\mathrm{PD}$ \\
\hline 8 & férfi & 51 & & lambda & II & - & PAD & igen & VGPR \\
\hline 9 & nő & 63 & $\operatorname{IgA}$ & kappa & I & $\operatorname{amp}(1 q)$ & VDT-PACE & igen & VGPR \\
\hline 10 & nő & 39 & & lambda & II & - & VDT-PACE & igen & VGPR \\
\hline 11 & férfi & 34 & IgG & kappa & II & $\mathrm{t}(4 ; 14)$ & VRD-PACE & igen & VGPR \\
\hline 12 & nő & 28 & IgG & kappa & II & $\operatorname{amp}(1 q)$ & VRD-PACE & tandem auto allo & PR \\
\hline 13 & nő & 41 & & lambda & III & $\operatorname{amp}(1 q)$ & EDAP & igen & PR \\
\hline 14 & férfi & 69 & IgG & lambda & III & $\operatorname{amp}(1 q)$ & IRD & nem & VGPR \\
\hline 15 & férfi & 45 & IgG & kappa & II & $\operatorname{amp}(1 q)$ & VTD-PACE & nem & $\mathrm{SD}$ \\
\hline 16 & férfi & 61 & IgG & kappa & II & - & KRD & terv & $\mathrm{PD}$ \\
\hline
\end{tabular}

IRD = ixazomib, lenalidomid, dexametazon; RD = lenalidomid, dexametazon; VRD = bortezomib, lenalidomid, dexametazon; VD-venetoclax = bortezomib, dexametazon, venetoclax; VDTC $=$ bortezomib, dexametazon, thalidomid, ciklofoszfamid; PAD = bortezomib, doxorubicin, dexametazon; VDT-PACE = bortezomib, dexametazon, thalidomid, ciszplatin, doxorubicin, ciklofoszfamid, etopozid; VRD-PACE = bortezomib, lenalidomid, dexametazon, ciszplatin, doxorubicin, ciklofoszfamid, etopozid; EDAP = etopozid, dexametazon, citarabin, ciszplatin; $\mathrm{KRD}=$ carfilzomib, lenalidomid, dexametazon; HD cyclo + Benda $/ \mathrm{Mel} \mathrm{ASCT}=$ magas dózisú ciklofoszfamid őssejt-mobilizálás, bendamustin, melfalán autológ őssejt-transzplantáció; N.A. = nincs adat, nem történt FISH-vizsgálat a diagnóziskor 


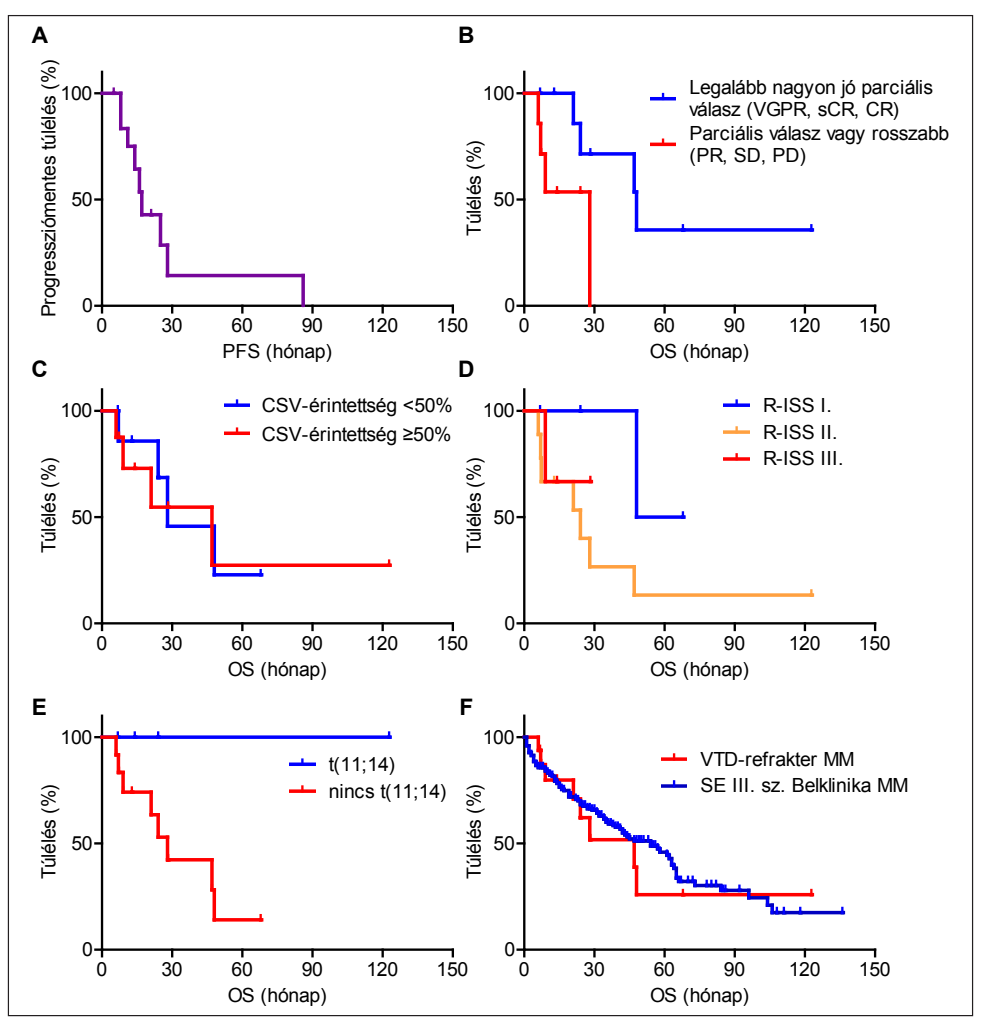

2. ábra. A VTD-refrakter betegek túlélési görbéi. A: progressziómentes túlélés (PFS), medián 17 hónap, B-F: össztúlélés (OS), B: salvage (másodvonalbeli) kemoterápiára adott válasz szerint $(P=0,0487)$, C: csontvelö- (CSV-) érintettség mértéke szerint $(P=$ $0,8038)$, D: R-ISS stádiumbesorolás alapján $(P=0,242)$, E: $\mathrm{t}(11 ; 14)$ transzlokáció esetén $(P=0,1081)$, F: túlélés összehasonlítása 230, a Semmelweis Egyetem III. sz. Belgyógyászati Klinikán kezelt myeloma multiplexes beteg adataival (medián 47 ill. 54 hónap, $P=0,9261$ )

tunk korrelációt (2C. ábra). Összehasonlítottuk az össztúlélést a különböző R-ISS-stádiumok szerint is. Tendencia látható az R-ISS 1. stádiumba tartozók kedvezőbb túlélésében, de ez a különbség nem ért el statisztikailag szignifikáns szintet (2D. ábra). Fontos megjegyezni azonban, hogy a csoportok kis elemszáma miatt a következtetések levonásának lehetősége ez esetben korlátolt. Érdekes megfigyelésünk, hogy mind a négy, t(11;14) transzlokációval bíró beteg elemzésünkkor még életben volt (2E. ábra), de a kis elemszám itt is behatárolja következtetési lehetőségeinket. A 16 VTD-refrakter beteg össztúlélése medián 47 hónapnak mutatkozott, ami meglepő módon nem tért el szignifikánsan 230 nem VTD-refrakter MM eset eredményeitől ( $2 F$. ábra).

\section{Megbeszélés}

Az MM kezelésében alkalmazott kemoterápiás szerekkel szembeni rezisztenciamechanizmusokról az utóbbi években sok új ismeretet szereztünk [7], de a tudásunk még közel sem teljes. Ismertek széles gyógyszerspektrumú rezisztenciamechanizmusok, de szerspecifikus folyamatokat is feltártak. A gyógyszereffluxért felelős MDR1 ABC transzporterről leírták, hogy az IMiD-ek és az alkiláló szerek is szubsztrátjai lehetnek, és bár diagnóziskor a myelomás sejtek nem fejezik ki az MDR1 transzportert, de a kezelés kiváltja annak sejtfelszíni kifejeződését [8,9]. Hasonlóan számos más tumorhoz, MM-sejtekben is kialakulhat rezisztencia alkilezőszerekkel szemben, melyet a DNS-hibajavító mechanizmusok valamilyen eltérése okoz. Például 1q21-amplifikációban az ILF2 overexpresszálódik, ami a DNS-hibajavító képességet növeli [10]. Az MMsejtek proteaszóma-inhibitorokkal szembeni igen nagy érzékenységének hátterében az MM-sejtek jelentős immunglobulin termelése áll: a proteoszómaműködés gátlásakor intracelluláris fehérjefelhalmozódás és endoplazmás retikulumstressz lép fel, ami az MM-sejtek apoptózisához vezet. Ezzel szemben nem szekretoros myelomában a tumorsejtek kisebb mértékü fehérjetermelése magyarázhatja a proteoszóma-inhibitorok csökkent hatékonyságát [11]. Érdekes módon a proteaszóma-inhibitorokkal szemben rezisztens betegekben az endoplazmás retikulumstressz szabályozásában szerepet játszó fehérjék mennyiségének eltéréseit találták, ami így az apoptózis elkerüléséhez vezethet [12]. Az IMiD szerek támadáspontja az E3 ubikvitin ligáz cereblon, mely a Cullin4-A és a DDB1 fehérjekkel alkotott fehérjekomplexen keresztül többek között az Ikaros és Aiolos transzkripciós faktorok múködését szabályozza. A cereblon útvonal számos elemének mutációját mutatták ki relabált/refrakter myelomás betegekben, ami érthetővé teszi az IMiD szerekkel 
szembeni rezisztencia kialakulását ezen esetekben [13]. A glükokortikoid receptort kódoló NR3C1 mutációja pedig a glükokortikoidokkal szembeni rezisztenciához vezet [14].

Bár a citogenetikai abnormalitásokat rutinszerűen meghatározzuk rizikóstratifikáció céljából, sajnos a drogrezisztencia szempontjából kevés információval bírnak. A hiperdiploid myelomában különösen hatékony lehet a lenalidomid-alapú terápia [15], míg t $(4 ; 14)$ transzlokáció esetén a proteaszóma-inhibitor bortezomibra alakulhat ki jó válasz [16], valószínűsíthetően ez igaz az új generációs proteaszóma-inhibitorokra is. A t $(11 ; 14)$ transzlokáció ciklin D1-overexpresszió mellett jellemzően emelkedett Bcl-2 fehérjekifejeződéssel is jár, így a Bcl-2-inhibitor venetoclax sokszor hatékony $\mathrm{t}(11 ; 14)$ abnormalitással bíró MM-ben [17].

Egy feltünő jelenség, hogy a VTD-refrakter betegcsoport fiatalabbnak bizonyul a VTD-vel kezelt, nem refrakter betegekkel összevetve, aminek a biológiai háttere nem világos. Ismert, hogy az idősebb populációban több a hiperdiploid, a fiatalabbak között az IgH-transzlokált myeloma, ez talán részben magyarázhatja ezt. Annyi konklúzió mindazonáltal levonható, hogy abban a ritka esetben, ha a myeloma fiatalabb beteget érint, érdemes fokozatosan figyelni a refrakteritás jeleire.

A transzplantálható korú betegpopulációban leggyakrabban alkalmazott protokoll Magyarországon a VTD, idősebb betegpopulációban a thalidomid és a bortezomib neuropathiát okozó hatása korlátozza együttes alkalmazásukat. Vizsgálatunkban VTD-terápiára refrakter betegek adatait elemeztük, a 10 éves időszakban 16 beteg felelt meg beválasztási feltételeinknek. Az alacsony szám mutatja, hogy primeren VTD-refrakter állapot szerencsére ritka. Nemzetközi tanulmányokban a refrakter esetek különvétele a relabált myelomától ritka, és általában összefoglalóan relabált/refrakter myelomáról beszélnek. Mivel azonban a refrakteritás és a relapszus eltérő biológiai folyamatokat tükröz, szükségesnek véltük a két betegcsoport megkülönböztetését. Vizsgálatunk nagy előnye, miszerint szelektíven a VTD-refrakter betegek adatait elemezte, egyben azzal a hátránnyal is bír, hogy nincs lehetőség adatainkat más munkacsoportok adataival közvetlenül összevetni az ilyen irányú vizsgálatok hiánya miatt. Megjegyzendő, hogy míg Európában, így Magyarországon is az IMiD szerek közül csak a thalidomid finanszírozott első vonalbeli kezelésben, az Egyesült Államokban a lenalidomid már teljesen átvette annak helyét első vonalban, ami háttérbe szorította a thalidomid-alapú protokollokat és a thalidomidot célzó vizsgálatokat. Mivel a lenalidomid jobb hatékonyságú és kedvezőbb mellékhatású szer, mint a thalidomid, és akár thalidomid-refrakter esetekben is hathat, ezért fontos elörelépés lesz, ha mi is alkalmazhatjuk első vonalban [5]. Hasonlóan, a proteaszóma-inhibitor bortezomib hatástalansága esetén is elérhetünk terápiás választ, ha újabb proteaszóma-inhibitorra váltunk. A carfilzomib hatékonyabb és kevesebb mellékhatással rendelkezik, mint a bortezomib, relapszus vagy refrakteritás esetén alkalmazhatjuk [18]. Az ixazomib elönye pedig az, hogy orálisan szedhető, szemben a parenterálisan alkalmazható többi proteaszóma-inhibitorral [19]. Vizsgálatunkban VTD-refrakteritás esetén számos hatékony másodvonalbeli protokollt alkalmaztunk, szerencsére mára széles terápiás választékkal bírunk. A különböző másodvonalbeli protokollok mind az eseti elbírálás hatását, mind a terápiás paletta időbeni bővülését mutatja. Másodvonalban a $\mathrm{t}(11 ; 14)$ transzlokáció esetén hatékony lehetőségnek tünik a terápia venetoclaxszal történő kiegészítése, egyebekben a szerzők a KRD és a VDTPACE protokollokat részesítik manapság előnyben. Fontosnak érezzük, hogy a VTD-refrakter betegek részesüljenek autológ őssejt-transzplantációban amint lehetséges, részben ennek tartjuk köszönhetőnek a meglepően jó túlélési eredményeket. Továbbá immunterápia (daratumumab) alkalmazásával is kedvező tapasztalataink vannak [6].

Megjegyzendő, hogy tapasztalataink alapján a komplex, kedvezőtlen citogenetikai eltérésekkel rendelkező MM kezelése a széles terápiás eszköztár ellenére sajnos továbbra sem megoldott. A rossz prognózisú VTD-refrakterek kis száma vizsgálatunkban annak tudható be, hogy a kedvezőtlen citogenetikájú betegeink többségénél is általában el lehet érni valamiféle választ (azaz nem ténylegesen refrakter), de ez a válasz a legtöbbször rövid idejú.

A refrakteritás felismerésének feltétele, hogy a szükséges kontrollvizsgálatok (elektroforézis, szabadkönnyülánc-vizsgálat) időben elvégezhetőek legyenek. A magyar gyakorlatban probléma, hogy a laborvizsgálatok finanszírozott elvégzése csak bizonyos időközönként lehetséges, így a labornak választania kell, hogy vagy visszautasítja, vagy veszteségesen végzi a vizsgálatot. Ha a laborvizsgálatok (pár ezer forintos) költségét összevetjük az alkalmazott gyógyszerekével (milliós), akkor érthetetlennek tünik a korlátozás, mégis, lévén hogy a finanszírozás külön forrásokból történik, helyben a kórházban sokszor nehéz a helyzetre megfelelő megoldást találni.

Fontos felismerése a tanulmányunknak, hogy nem csak az ismert prediktorok alapján rossz prognózisú betegek esetében számíthatunk VTD-refrakteritásra. Mi több, vizsgálatunkban a VTD-refrakterek többsége kis vagy közepes rizikóval rendelkező beteg volt az R-ISS-besorolásnak megfelelően. Eredményeink alapján elmondható, hogy a hagyományos prognosztikai faktorok nem alkalmasak a VTD-refrakteritás előrejelzésére. Adataink felhívják a figyelmet új markerek szükségességére, hogy ezek a betegek hamarabb juthassanak hatékony terápiához.

Nyilatkozat: A kézirat korábban más folyóiratban nem jelent meg, és máshova beküldésre nem került. A levelező szerző elolvasta a Hematológia-Transzfuziológia szerzői útmutatóját.

Érdekeltségek: A szerzőknek nincsenek érdekeltségeik. 
Anyagi támogatás: A közlemény anyagi támogatásban nem részesült.

Szerzői munkamegosztás: A betegek kezelésében és az adatgyüjtésben valamennyi szerző részt vett. A tanulmány koncepciójának kidolgozását V.G. és M.G. végezte. A statisztikát T.A.D. készítette. A cikk végleges változatát valamennyi szerző elolvasta és jóváhagyta.

Köszönetnyilvánítás: Az adatgyüjtést és feldolgozást részben az NVKP_16-1-2016-0005 számú projekt támogatta.

\section{Irodalom}

[1] Varga G, Mikala G, Varoczy L, et al. Management of multiple myeloma in Hungary in 2016. [A myeloma multiplex megközelítése Magyarországon 2016-ban.] Orv Hetil. 2016; 157: 123-137. [Hungarian]

[2] Varga G, Mikala G, Andrikovics H, et al. How long does a myeloma patient currently wait for the diagnosis in Hungary? [Mennyit vár ma Magyarországon egy myelomás beteg a diagnózisig?] Orv Hetil. 2014; 155: 1538-1543. [Hungarian]

[3] Manier S, Salem KZ, Park J, et al. Genomic complexity of multiple myeloma and its clinical implications. Nat Rev Clin Oncol. 2017; 14: $100-113$.

[4] Palumbo A, Avet-Loiseau H, Oliva S, et al. Revised International Staging System for Multiple Myeloma: A Report From International Myeloma Working Group. J Clin Oncol. 2015; 33: $2863-$ 2869.

[5] Sonneveld P, Avet-Loiseau H, Lonial S, et al. Treatment of multiple myeloma with high-risk cytogenetics: a consensus of the International Myeloma Working Group. Blood 2016; 127: 2955-2962.

[6] Lovas S, Varga G, Farkas P, et al. Real-world data on the efficacy and safety of daratumumab treatment in Hungarian relapsed/refractory multiple myeloma patients. Int J Hematol. 2019

[7] Harding T, Baughn L, Kumar S, et al. The future of myeloma precision medicine: integrating the compendium of known drug resistance mechanisms with emerging tumor profiling technologies. Leukemia 2019; 33: 863-883.

[8] Abraham J, Salama NN, Azab AK. The role of P-glycoprotein in drug resistance in multiple myeloma. Leuk Lymphoma 2015; 56: 26-33.
[9] O'Connor R, Ooi MG, Meiller J, et al. The interaction of bortezomib with multidrug transporters: implications for therapeutic applications in advanced multiple myeloma and other neoplasias. Cancer Chemother Pharmacol. 2013; 71: 1357-1368.

[10] Marchesini M, Ogoti Y, Fiorini E, et al. ILF2 is a regulator of RNA splicing and DNA damage response in 1q21-amplified multiple myeloma. Cancer Cell 2017; 32: 88-100 e106.

[11] Paiva B, Puig N, Cedena MT, et al. Differentiation stage of myeloma plasma cells: biological and clinical significance. Leukemia 2017; 31: 382-392.

[12] Dytfeld D, Luczak M, Wrobel T, et al. Comparative proteomic profiling of refractory/relapsed multiple myeloma reveals biomarkers involved in resistance to bortezomib-based therapy. Oncotarget 2016; 7: 56726-56736.

[13] Kortum KM, Mai EK, Hanafiah NH, et al. Targeted sequencing of refractory myeloma reveals a high incidence of mutations in CRBN and Ras pathway genes. Blood 2016; 128: 1226-1233.

[14] Sanchez-Vega B, Gandhi V. Glucocorticoid resistance in a multiple myeloma cell line is regulated by a transcription elongation block in the glucocorticoid receptor gene (NR3C1). Br J Haematol. 2009; 144: 856-864.

[15] Vu T, Gonsalves W, Kumar S, et al. Characteristics of exceptional responders to lenalidomide-based therapy in multiple myeloma. Blood Cancer J. 2015; 5: e363.

[16] Avet-Loiseau H, Leleu X, Roussel M, et al. Bortezomib plus dexamethasone induction improves outcome of patients with $t(4 ; 14)$ myeloma but not outcome of patients with del(17p). J Clin Oncol. 2010; 28: 4630-4634

[17] Kumar S, Kaufman JL, Gasparetto C, et al. Efficacy of venetoclax as targeted therapy for relapsed/refractory $\mathrm{t}(11 ; 14)$ multiple myeloma. Blood 2017; 130: 2401-2409.

[18] Dimopoulos MA, Goldschmidt H, Niesvizky R, et al. Carfilzomib or bortezomib in relapsed or refractory multiple myeloma (ENDEAVOR): an interim overall survival analysis of an openlabel, randomised, phase 3 trial. Lancet Oncol. 2017; 18: 13271337.

[19] Dimopoulos MA, Gay F, Schjesvold F, et al. Oral ixazomib maintenance following autologous stem cell transplantation (TOURMALINE-MM3): a double-blind, randomised, placebo-controlled phase 3 trial. Lancet 2019; 393: 253-264.

A cikk a Creative Commons Attribution 4.0 International License (https://creativecommons.org/licenses/by/4.0/) feltételei szerint publikált Open Access közlemény, melynek szellemében a cikk bármilyen médiumban szabadon felhasználható, megosztható és újraközölhető, feltéve, hogy az eredeti szerző és a közlés helye, illetve a CC License linkje és az esetlegesen végrehajtott módosítások feltüntetésre kerülnek. (SID 1) 